„Bohemistyka” 2021, nr 3, ISSN 1642-9893

Josef ŠTĚPÁN

DOI: $10.14746 /$ bo. 2021.3 .3

Univerzita Karlova

\section{Příčinnostní (kauzalitní) věty}

Keywords: causality clauses, causality conjunctions, adverbial subordinate clauses Klíčová slova: prríčinnostní věty, př́icinnostní spojky, př́ílovečné vedlejší věty

\section{Abstract}

The paper deals with a classification of causality adverbial subordinate clauses according to the hypotactic causality conjunctions: causal (protože, poněvadž, jelikož, ježto), final (aby), conditional (jestliže, kdyby, -li, pakli, jestli, pakliže), concessive (ač, ačkoli, prestože, třebaže, jakkoli, $i$ když, i kdyby, byt), and effect ( takže). Further on, the author classifies clauses with the conjunctions že, aby that gain a causality meaning in cooperation with the expressions in the head clause (proto; tak; diky tomu; z toho důvodu; kvi̊li tomu; za účelem toho; v prípadě; za predpokladu; $i$ pres to; vzdor tomu etc.). Some temporal conjunctions (když, pokud, jakmile) gain the meaning of causality only in the context of the complex sentence. Causality clauses are frequent in scientific texts.

Článek se zabývá klasifikací příslovečných příčinnostních vedlejších vět podle podřadicích př́ičinnostních spojek: příčinné (protože, poněvadž, jelikož, ježto), účelové (aby), podmínkové (jestliže, kdyby, -li, pakli, jestli, pakliže), príípustkové (ač ačkoli, přestože, třebaže, jakkoli, i když, i kdyby, byt'), účinkové (že, aby, až, takže). Autor dále klasifikuje prŕčinnostní věty se spojkami že, $a b y$, které získávají př́íčinnostní význam v kooperaci s výrazy v ř́́dící větě (proto; tak; diky tomu; z toho důvodu; kvůli tomu; za účelem toho; v př́padé; za predpokladu; i přes to; vzdor tomu atd.). Některé časové spojky nabývají př́činnostní význam až v souvětném kontextu ( $k d y z ̌$, pokud, jakmile). Př́činnostní věty jsou frekventované ve vědeckých textech.

\section{0. Úvodem}

Příčinnostní vedlejší věty závisejí na přísudku věty řídící a jsou, jak známo, po větách místních, časových a způsobových čtvrtým základním druhem př́islovečných vedlejších vět. Na rozdíl od uvede- ných tř̌́ druhů vět, jež jsou jen okolnostními (vnějšími) určeními, vyjadřuií příčinnostní věty „,vnitřní vztahy mezi jevy” (Svoboda 1954, s. 11; Smilauer 1966, s. 308), které jsou, viděno filozoficky, jednou z forem objektivního světa (Štěpán 1975, s. 305), vnitřní vztahy znamená, že jeden jev vyvolává jiný jev.

$\mathrm{Na}$ rozdíl od jiných větných členů, které se vyjadřují především nevětně, se př́ślovečné určení př́ŕčnnosti vyjadřuje stejně často nevětně i vedlejší větou, vedlejší věta je primárním vyjádřením př́ičinnosti (Nebeská 1985, s. 134). Nebudu proto přihlížet k nevětnému vyjadřování příčinnostních vět. ${ }^{1}$ Rozhodující pro poznání př́ičinnostních vět jsou vedle otázek jako proč, za jakým účelem, za jaké podminky apod. podle mého názoru podřadicí spojky, které jsou v souvětí syntakticky aktivní. Jsou to především spojky s př́ícinnostním významem a dále spojky že a aby, které získávají př́íčnnostní význam díky nejrůznějším výrazům v rííící větě.

Celoživotně se problematice souvětné př́činnosti věnoval v řadě studií K. Svoboda, vztahy mezi příčinou a následkem a mezi důvodem a důsledkem se zabývá i jeho poslední závažná stat' (Svoboda 1985), kde je uvedena bibliografie jeho prací. ${ }^{2}$ Knihy o příčinnosti napsali Machová (1972), která ji popsala nejen v souvětí, ale především ve větě jednoduché, Karlík (1995), jenž charakterizuje souvětnou př́íinnost $\mathrm{z}$ hlediska komunikačně pragmatického, a Pešek při konfrontaci francouzštiny a češtiny (2011). Popis prríčinnostních vět je ve všech českých mluvnicích a v rozsáhlé zahraniční lingvistice, kterou uvádí Karlík, Nekula, Pleskalová (2016). Nejnovější podrobné výklady o příčinnostních větách jsou v knize Souvětí současné češtiny (Štěpán 2013 , s. 46, 58-70, 77-78). Inspirací byla kniha Souvétí spisovné češtiny (Svoboda 1972, s. 146-148, 191-214). V poslední době psal o těchto větách také Štícha (2013, s. 833-851).

${ }^{1}$ Tomu věnoval nedávno pozornost ve studentských projevech Dvořák (2008-2009), který navázal na Svobodu (1976, s. 106).

${ }^{2}$ Překvapuje, že Rysová (2013) nezná práce tohoto našeho předního syntaktikabohemisty. Zikánová a kol. (2015) a Rysová (2018) neuvádějí základní Svobodovu knihu z roku 1972. Romanista Pešek (2011) Svobodovy práce cituje. 
Cílem přispěvku je zabývat se především jednotlivými druhy příčinnostních vět, tj. větami př́činnými a důvodovými, účelovými, podmínkovými, prípustkovými a účinkovými (1). Dále si všimnu frekvence těchto prríčinnostních vět ve vědeckých textech a budu tuto frekvenci interpretovat (2). Navazuji na školské výklady o př́činnosti, prohlubuji je o nové vědecké poznatky a systematizuji je. ${ }^{3}$

\section{Příčinnostní věty}

Př́i č i nné ${ }^{4}$ a d ůvo d o vé vě ty jsou uvozeny základní spojkou protože, poněvadž je mírně knižní, jelikož bývala zcela knižní, ale v poslední době dochází k jejímu přehodnocování, ježto archaická; tyto spojky vyjadřují př́ícinu a důvod. Nejnověji se jimi zabýval i na základě zahraniční literatury článek O. Kleina (2009). Př́í č in a je fyzický jev, který bezprostředně vyvolává jiný fyzický jev, srov. Zvednutá kniha má energii, protože na ni pưsobi energie, která ji táhne dolù. Mnohem častěji ovšem nemáme na mysli vztah mezi jevy objektivní skutečnosti samé, nýbrž způsob, jak člověk tento vztah chápe; jde už o důvod (motivaci), kterým se vysvětluje jistá činnost, nebo chování lidí, srov. Předchozi noc nebyl doma, protože jel domi̊ $k$ matce. Při jazykovém vyjádření se uvedený rozdíl mezi př́ičinou a důvodem neprojevuje, proto pro zjednodušení $\mathrm{v}$ obou př́padech uvažuji o příčině, o větách př́činných. Od ů v o d u ve smyslu argumentačním, kdy mluvčí zdůvodňuje nějakou svou domněnku, uvažuji v souvětí Na tribunu pod střechu se asi nedostaneme, protože je hřiště oplocené, kde domněnku v řídící větě vyjadřuje slovo asi. Příčina a důvod se nevyjadřují jen uvedenými podřadicími spojkami, ale také

${ }^{3}$ Příčinnostní věty, jež popisuji, jsou - není-li uvedeno jinak - z elektronického korpusu psaných textů SYN, který je veřejně př́stupný v Českém národním korpusu na adrese: www.korpus.cz. Tam je možno zjistit jejich autory a vyhledávat další doklady.

${ }^{4}$ Př́ičinné (kauzální) věty jsou jen jedním z druhů příčinnostních (kauzalitních) vět. hlavními větami př́ičinnými a důvodovými se spojkami s nebot, $v \check{z} d y t^{\prime}$, totiž. ${ }^{5}$

Příčinná spojka protože může mít i dvouslovnou variantu s př́íslovcem proto $\mathrm{v}$ řídící větě a se spojkou že ve větě vedlejší, je-li ve větě řídící ještě omezující nebo zdưrazňující výraz (např.jen), srov. Zmínil jsem se o tom jen proto, že si to Amos přál. Vedle příčinných spojek se př́íčinné věty vyjadřují i nejrůznějšími primárními a sekundárními předložkami se zájmenem to $\mathrm{v}$ řídící větě a spojkou že v příčinné větě, srov. Noha mě boli jen od toho, že se na ni dívám. - Zemřel na to, že mél kameny $v$ žlučníku a pak něco s játry. - Žije díky tomu, že zapominá. - Tento konfliktní stav nevznikl následkem toho, že Jelcin rozehnal parlament. Ve větě rrídící bývá se zájmenem ten i multiverbizační jednotka, ${ }^{6}$ ve větě příčinné že, srov. Chtělo se mi řvát z toho di̊vodu, že Nad'a už tu není.

Spojka že může v mluvené řeči sama vyjadřovat příčinu, srov. Jsem na tebe pyšná, žes ( $\rightarrow$ protože jsi) ji to tak pěkně řekla.

Ú č e lov é věty jsou uvozeny spojkou aby a vyjadřují záměrnou činnost podmětu věty řídící, srov. Napřáhl roztřesenou ruku, aby je srdečně přivital. V knize se účelem zabýval polský lingvista Grochowski (1980). Účelová věta bývá zpravidla chápána jako děj, který byl způsoben něčí vưlí; účelová věta děj jen označuje, jeho realizaci však neoznamuje, a proto je amodální. Na rozdíl od toho mohu uvažovat o účelnosti tehdy, jestliže děje vyplývají z prrírodních dějů a jestliže tedy nevyjadřují záměrnou činnost, jsou neuvědomělé, srov. Podřizení vlci maji ocas svěšený, aby ukázali submisivitu.

Při zdůraznění účelové věty bývá ve větě řídící př́íslovce proto, srov. Déláš to jen proto, abys něco dělal. Účelová věta je vedle spojky $a b y$ ve vedlejší větě vyjádřena primárními a sekundárními předložkami se zájmenem to ve větě rídící, srov. Vězení jsou dobrá jen k tomu,

\footnotetext{
${ }^{5}$ Př́ičinu z druhé strany vyjadřují hlavní věty následkové a důsledkové (Svoboda 1984, pozn. 6 na s. 293) se spojkami proto, tedy, tudiž, a proto, a tedy, a tak.

${ }^{6}$ Multiverbizační jednotka je víceslovná jednotka, která vzniká na pozadí jednoho slova: $z$ toho důvodu $\leftarrow$ proto. O termínu ,multiverzizace” psal Jedlička (1969)
} 
aby se zdálo, že soudy a policie účinně působí. - Je to otrava, když musí David večer z domu jen kvi̊li tomu, aby nabral krev. - Nemá vůbec cenu bilancovat za účelem toho, aby to bylo lepší, protože mnohé prostě neovlivníme. Ve větě rrídící bývá se zájmenem ten i multiverbizační jednotka, srov. Penize jsou obvykle ukládány za tím účelem $(\leftarrow$ proto), aby v budoucnu zajistili finanční nezávislost.

P o d mín k o v é v ě t y jsou uvozeny základními spojkami jestliže, $k d y b y$, spojky -li a pakli jsou knižní, jestli hovorové, v poslední době se obnovuje v užívání knižní spojka pakliže. Podmínkovými větami se zabýval knižně český rusista Kubík (1967). Podmínkovou spojkou mohou být i spojky, které jinak mívají také jiný význam, např. když, pokud. Hlavním rysem podmínkových vět je, že vyjadřují děj amodálně, což znamená, že větou podmínkovou jako uvažovaným předpokladem děje věty řídící se vyjadřuje děj (stav), aniž se uvádí do vztahu ke skutečnosti. Tím se liší od vět příčinných, které jsou modální, protože oznamují děj. Podmínkovou větu nevztahujeme ke skutečnosti někdy proto, že nevíme, zda děj je reálný, jindy proto, že chceme vztah vyjádřit jako obecně platný, srov. Jestliže se nám dostane odpovědi na náš inzerát, ověrím si to ostatně velmi jednoduchou zkouškou. Podmínka nereálná je v souvětí Kdyby bylo všechno v bezvadném pořádku, risknul bych to.

U podmínkových spojek bývá v řídící větě při zdůraznění vedlejší věty př́slovce tehdy, srov. Máte pravomoc zastavit elektrárnu jen teh$d y$, jestliže jste výkonným ředitelem, pane Parksi. - Zpravidla v tom bytě bydlel a mizel jen tehdy, když Josefina Papetová čekala hosty. Podmínková věta je vedle spojky že, která uvozuje vedlejší větu, vyjádřena ve větě řídící sekundární předložkou a genitivem zájmena to, srov. V prípadě toho, že by se pojištovna dostala do potǐži, mưže ministerstvo financí rozhodnout o dalším použití těchto prostředků. Dále se tato věta vyjadřuje i multiverbizační jednotkou, srov. Rozhodující je ta skutečnost, pracovni poměr vzniká volbou v tom př́padě, že zvolený dosud nebyl v pracovním poméru k tomu zaměstnavateli. Multiverbizační jednotka bývá v řídící větě i u podmínkových spojek, srov. Tuto daň není povinen platit v tom př́padě ( $\leftarrow$ tehdy), jestliže daňová povinnost vznikla již držiteli vozidla.

Př í p u s t k o v é v ě t y vyjadřují děj, který je v rozporu s dějem věty řídící. Jsou uvozeny jednoznačnými spojkami $a \check{c}$, ačkoli(v), prestože, třebaže, třeba(s), knižní jakkoli(v), dále $i k d y z ̌$ (ani když), i kdyby (ani kdyby), knižní a zastaralé $a c ̌ l i$, knižní až archaické byt' (i). Liší se od příčinných vět, které jsou oznamovací, a podmínkových vět, jež jsou amodální, v tom, že přípustkové věty jsou bud' oznamovací, nebo amodální, nebo jsou modálně dvojznačné, což se projevuje i v inventáři spojek.

Př́ípustkové věty o $\mathrm{z} \mathrm{n}$ a $\mathrm{m}$ o v a c í jsou uvozeny spojkami $a \check{c}$, ačkoli(v), přestože, třebas, třebaže a je možné je převést na věty příčinné, přičemž hlavní věta kladná se změní na zápornou a obráceně věta záporná na kladnou; tím se ovšem zruší rozpor mezi fakty obou vět, srov. Ačkoli jsme na tom v rodině nebyli špatně, máma odmítala mě módně strojit $\rightarrow$ Protože jsme na tom v rodině nebyli špatně, máma neodmítala mě módně strojit. Př́ípustkovou větu je možno ještě srovnat se souvětím, v němž hlavní věty jsou v poměru odporovacím, srov. Nebyli jsme na tom špatně, ale máma mé odmitala módně strojit.

Př́ípustkové věty a m o d á 1 n í jsou uvozeny spojkami $i k d y b y$, ani $k d y b y$. Výslovně nevypovídají o ději, který by byl oznamovací, srov. I kdyby prišel pozdě, počkaji na néj.

Nejčastěji jsou př́ipustkové věty uvozeny spojkou $i k d y z ̌$ a jsou m o d á 1 n ě d v o j z n a č n é. Jestliže věta vyjadřuje děj jen jako myšlený, je věta amodální a spojku $i$ když nelze nahradit spojkou ačkoli, která má oznamovací modálnost, srov. I když oheň zvládneme, pořádně zamává se systémy. Jindy je věta s $i$ když modální, vyjadřuje oznámení a je možno ji nahradit spojkou ačkoli, srov. I když byl již středního věku, tedy žádný zajíc, stále byl svobodný. Modálně dvojznačná je také spojka byt', byt'i.

Př́ipustkové věty bývají uvozeny i spojkou že, a to v součinnosti s primárními a sekundárními předložkami a zájmenem to ve větě řídící, srov. I přes to, že jsme začali poslední, byli jsme z baráku hotovi první. - Ale tohle mě jen tak napadlo, navzdory tomu, že žádný důvod 
k takovému tvrzení nemám. - Také sklep je barevný, vzdor tomu, že $v$ něm běháme potmě. Ve větě řídící bývá i multiverbizační jednotka, srov. Prohlubuje stíny dokonce i za tu cenu, že se tím někdy dostává na samu hranici dobrého stylu.

Ú č i n k o v é v ě t y. Starší české mluvnice považovaly tyto věty za druh vět zpo̊sobových. Účinková věta však vyjadřuje vnitřní vztah mezi jevy, totiž ,účinek nějakého způsobu děje nebo míry děje, resp. vlastnosti naznačené ve větě řídící, ne však sám způsob, není tedy druhem věty způsobové.” (Svoboda 1972, s. 157) Na toto Svobodovo pojetí vět účinkových jako příčinnostních navázala většina současných českých mluvnic.

Účinkové věty jsou uvozeny spojkami že, $a b y, a z ̌$ a takže. Měrově účinkové věty vyjadřují účinek vysoké nebo nízké míry děje, který je vyjádřen ve větě rídící, srov. Probírali tu príhodu tak $(\rightarrow$ tolik) podrobně, že se oba vzrušili. - Tyhle věci vás musí stát hrozně času, že tady nikdy nejste na prvni hodinu. - Alespoň mohli být tak chytří, aby do svých sebejistých prohlášeni vnesli trochu pochybností. - Přitiskl ji k sobě tak silně, až vykřikla. - Strašně lilo, takže ani zvonkohra nebyla tak uklidňující jako jindy. Méně časté jsou způsobově účinkové věty, které vyjadřují účinek nějakého způsobu děje, srov. [p]ouhý lipový list je tvarován tak ( $\rightarrow$ takovým způsobem), že v miniature odráži stavbu a tvar celé koruny budoucího stromu. (V. Körner) - Ale přijed' raději ( $\rightarrow$ tak, takovým způsobem), aby tě nikdo neviděl. Účinkové, věty je třeba je lišit od vět důsledkových, u nichž předcházející věta nevyjadřuje míru, srov. Paní Irena určitě nebude ještě vzhưru, takže $(\rightarrow$ a proto) nám nechá volné pole.

Konečně je třeba zmínit věty, v nichž některé další spojky než že a $a b y$ samy o sobě nemají prííčinnostní významy, takové významy nabývají až v k o n textu. Můžeme se o tom přesvědčit tím, že je nahradíme příčinnostními spojkami. Jsou to především věty s časovými spojkami, srov. Lekla se, když ( $\rightarrow$ protože) ho uviděla. - Když $(\rightarrow$ jestliže) se člověk dlouho opaluje, zvýrazní to vrásky. - Züstane u nás týden, pokud $(\rightarrow$ jestliže) proti tomu nebudete nic namítat. -
Jakmile $(\rightarrow$ jestliže) se voda vyvaři, odejdeme. O některých těchto spojkách jsem se už zmínil u vět podmínkových.

\section{Frekvence příčinnostních vět ve vědeckých textech}

Příčinnostní věty mají důležitou funkci ve vědě. Výzkumem 34021 př́ičinnostních vět ve vědeckých textech filozofie, sociologie, politologie, psychologie, estetiky, etiky, pedagogiky, logiky, práva, etnologie, demografie, hudební vědy, literární vědy, lingvistiky, matematiky, fyziky, astronomie a chemie jsem podrobně zjišt'oval frekvence jednotlivých druhů př́činnostních vět. Dlouhý seznam současných textů uvedených vědních oborů uvádí Štěpán (2012, s. 91-94).

$\mathrm{V}$ tabulce jsou uvedeny nejen podřadicí spojky s jednoznačnými příčinnostními významy (protože, jestliže, $i$ když atd.), ale i další podřadicí spojky, které příčinnostního významu nabývají samy až v kontextu (např. podmínkové $k d y z ̌$ apod.), nebo ho nabývají v součinnosti $\mathrm{s}$ primárními a sekundárními předložkami a se zájmenem to $\mathrm{v}$ řídící větě (napřr. příčinné díky tomu, že apod.), nebo v součinnosti s multiverbizační jednotkou v řídící vět ( $z$ toho diovodu, že) nebo v součinnosti s příslovci v řídící větě (příčinné proto, že, účelové proto, aby, podmínkové tehdy, když atd.), ale i jinak (podmínkové v př́padě, že). Podrobněji se podřadicími spojkami (částicemi) že, $a b y$, které získávají příčinnostní význam díky výrazům v řídící větě, zabýval Štěpán (2011).

Tabule 1. Seznam druhů příčinnostních vedlejších vět uspořádaný podle klesající frekvence podřadicích spojovacích výrazů

\begin{tabular}{|c|l|c|c|l|c||}
\hline Pořadí & Druh věty & Frekvence & Pořadí & Druh věty & Frekvence \\
\hline 1. & - li & 10657 & 30. & za to, že & 57 \\
\hline 2. & protože & 3970 & 31. & díky tomu, že & 54 \\
\hline 3. & pokud & 3541 & 32. & tehdy, pokud & 57 \\
\hline 4. & jestliže & 2580 & 33. & pakli(že) & 41 \\
\hline 5. & i když & 2184 & 34. & $\begin{array}{l}\text { navzdory tomu, } \\
\text { že }\end{array}$ & 34 \\
\hline 6. & aby (účelové) & 2015 & 35. & tehdy, kdyby & 24 \\
\hline
\end{tabular}




\begin{tabular}{|c|c|c|c|c|c|}
\hline 7. & proto, že & 1418 & 36. & za podmínky, že & 21 \\
\hline 8. & ačkoli(v) & 958 & 37. & třeba(s) & 20 \\
\hline 9. & kdyby & 899 & 38. & jestli & 19 \\
\hline 10. & $\begin{array}{l}\text { když } \\
\text { (podmínkové) }\end{array}$ & 849 & 39. & právě tehdy, -li & 18 \\
\hline 11. & přestože & 582 & 40. & $\begin{array}{l}\mathrm{y} \text { důsledku toho, } \\
\text { že }\end{array}$ & 17 \\
\hline 12. & jelikož & 410 & 41. & $\mathrm{z}$ toho, že & 14 \\
\hline 13. & $\mathrm{v}$ případě, že & 370 & 42. & když (př́íčinné) & 14 \\
\hline 14. & poněvadž & 348 & 43. & kvůli tomu, že & 12 \\
\hline 15. & byt' & 318 & 44. & na to, aby & 11 \\
\hline 16. & třebaže & 311 & 45. & že (příčinné) & 9 \\
\hline 17. & proto, aby & 299 & 46. & ani když & 9 \\
\hline 18. & právě tehdy, když & 290 & 47. & proto, poněvadž & 6 \\
\hline 19. & tehdy, když & 275 & 48. & ani kdyby & 6 \\
\hline 20. & jakkoli(v) & 262 & 49. & $\begin{array}{l}\text { za tím účelem, } \\
\text { aby }\end{array}$ & 5 \\
\hline 21. & ač & 239 & 50. & ježto & 4 \\
\hline 22. & tehdy, -li & 225 & 51. & důvodem toho, že & 3 \\
\hline 23. & $\mathrm{k}$ tomu, aby & 159 & 52. & $\begin{array}{l}\text { důsledkem toho, } \\
\text { že }\end{array}$ & 2 \\
\hline 24. & právě když & 149 & 53. & kvůli tomu, aby & 2 \\
\hline 25. & tehdy, jestliže & 144 & 54. & $\begin{array}{l}\mathrm{z} \text { toho důvodu, } \\
\text { aby }\end{array}$ & 2 \\
\hline 26. & za předpokladu, že & 144 & 55. & $\underset{\mathrm{Ze}}{\text { pod podmínkou, }}$ & 2 \\
\hline 27. & i kdyby & 119 & 56. & $\begin{array}{l}\text { právě tehdy, jest- } \\
\text { liže }\end{array}$ & 1 \\
\hline 28. & přesto, že & 107 & 57. & vlivem toho, že & 1 \\
\hline 29. & $\mathrm{z}$ toho důvodu, že & 86 & celkem & & 34021 \\
\hline
\end{tabular}

mínkové věty dále plní ve vědeckých textech, jež mají složitější myšlenkovou strukturu než jiné texty, často funkci textových orientátorů, které usnadňují recepci textu, srov. Shrneme-li základní linii této kapitoly, můžeme řici, že všichni autoři ve větši či menši míre opouštěli predstavu $[\ldots]$.

Na druhém místě jsou věty př́icinné (protože, jelikož, poněvadž), což je dáno výkladem ve vědeckých textech, při němž se vysvětlují společenské a prírodní jevy. Tyto věty vysvětlují a interpretují především sociální jevy v nejrůznějších vědách.

Třetím druhem nejčastějších příčinnostních vět jsou věty přípustkové ( $i k d y z$, ačkoli), které hlavně ve společenskovědních textech vyjadřují rozpornost světa. Jsou jedním z mála gramatických prostředků, jež jsou př́́mo spojeny s mimojazykovou skutečností (Svoboda 1974, s. $68 \mathrm{n}$.).

Vyšší frekvence účelové věty s aby je dána funkcí textového orientátora, srov. Abychom mohli podat obecnou definici pojmu splňování $v$ L, je nutno zavést interpretaci mimologických konstant $v L$.

\section{Závěr}

Problematika př́činnostních vět je složitá, jak ukazuje dosavadní jazykovědná literatura, která má rưzná teoretická východiska. Soustředil jsem se zde především na doložené příčinnostní věty, které jsem popsal. V minulosti jsem se zabýval tím, jak obsahová kategorie kauzality je vyjadřována napříc rovinami jazykového systému, a to na rovině souvětněčlenské, větněčlenské i morfologické (Štěpán 1988).

Při klasifikaci příčinnostních vět jsem rozlišil věty př́řcinné a důvodové, charakterizoval jsem věty podmínkové jako amodální, věty přípustkové jako modální, amodální a modálně dvojznačné, věty účinkové jako měrově účinkové a způsobově účinkové

Uvedl jsem frekvenci příčinnostních vět ve vědeckých textech, pro které jsou tyto věty příznačné, a tuto frekvenci jsem interpretoval. Nezabýval jsem se frekvencí účinkových vět. $\mathrm{v}$ textech přrrodních i společenských věd, vůbec nejčastějš́ jsou v textech $\mathrm{z}$ oblasti fyziky, matematiky, dále $\mathrm{v}$ logice a lingvistice. Pod- 


\section{Literatura}

Dvořák K., 2008/2009, Vyjadřování přičinnostnich vztahů pomocí předložek a spojek ve studentských projevech, „Český jazyk a literatura” 59, s. 233-236.

Groch ow ski M., 1980, Pojęcie celu - studia semantyczne. Wrocław: Zakład Narodowy im. Ossolińskich.

J e d 1 i č k a A., 1969, Univerbizace a multiverbizace v pojmenovacích strukturách. In V. Barnet, F. Buriánek, M. Drozda, A. Jedlička, J. Porák, M. Romportl, Z. Urban (eds.), Slavica Pragensia 11. Praha: Univerzita Karlova, s. 93-101.

Ka r lík P., 1995, Studie o českém souvětí. Brno: Masarykova univerzita.

Karlík P., Nekula M., P le skalová J. (eds.), 2016, Nový encyklopedický slovnik češtiny. Praha: Nakladatelství Lidové noviny.

K 1 e in O., 2009, Argument vs. vysvětlení: př́pad souvětí přičinného typu. „Slovo a slovesnost" 70, s. 100-112.

K u bík M., 1967, Uslovnyje konstrukcii i sistema složnogo predloženija. Praha.

M a c h o vá S., 1972, Přičina v syntaxi češtiny. Praha: Academia.

N e b e s k á I., 1985, Kvantitativní charakteristiky souvětí. In M. Těšitelová a kol., Kvantitativní charakteristiky současné češtiny. Praha: Academia, s. 126-141.

P e š e k O., 2011, Argumentativni konektory v současné francouzštině a češtině. České Budějovice: Jihočeská univerzita v Českých Budějovicích.

Rysová M., 2013, Způsoby vyjadřování vztahu př́ćciny a důsledku v textu alternativy pro »proto« a »protože», „Didaktické studie” 5 (2), s. 39-54.

R y s ová M., 2018, Diskurzní konektory v češtině. Od centra $k$ periferii. Praha: Ústav formální a aplikované lingvistiky.

S v o b o d a K., 1954, O tzv. větách přičinných a účinkových. „Naše řeč” 37, s. 1-14.

S v o b o d a K., 1972, Souvětí spisovné češtiny. Praha: Universita Karlova.

S v o b o d a K., 1974, Časové rozvrstvení př́pustkových spojek v současné spisovné češtinè, „Naše řeč” 57, s. 67-71.

S v o b o d a K., 1976, Stylizační výcvik ve spisovné češtině a rozvoj myšlení II. Praha: Státní pedagogické nakladatelství (učební text).

S v o b od a K., 1984, Zámérová modálnost a syntaktická stavba souvětí. „Slovo a slovesnost" 45, s. 289-296.

S vo bod a K., 1985, Dưvod a přičina, ,Slovo a slovesnost” 46, s. 275-283.

Š m i 1 a u e r V., 1966, Novočeská skladba. Praha: Státní pedagogické nakladatelství.

Š tě pán J., 1975, K pojetí kauzality, zvláště v jazyce, „Slovo a slovesnost” 36, s. $305-310$.

Š tě pá n J., 1988, Systémový a odrazový charakter kategorie kauzality v současné češtině. „Slavia” 57, s. 190-201.

Š tě pá n J., 2011, Přičinnostní vedlejši věty zájmenně-částicové. „Korpus - gramatika-axiologie" 4, s. 46-56.
Š tě pá n J., 2012, Přičinnostní vedlejši věty z hlediska kvantitativního (na materiálu védeckých textů), ,Jazykovědné aktuality” 49, s. 79-94.

Š t ě pá n J., 2013, Souvětí současné češtiny. Liberec: Technická univerzita v Liberci [online: https://sites.google.com/site/mluvnicecestiny/publikacni-vystupy]

Št í c h a F., 2013, Gramatika souvětí. In F. Štícha a kol., Akademická gramatika spisovné češtiny. Praha: Academia, s. 833-851.

Zikánová Š., Poláková L., Jínová P., Nedoluzhko A., Rysová M., Mírovský J., Hajičová E., 2015, Zachyceni výstavby textu v Pražském závislostním korpusu, „Slovo a slovesnost” 76, s. 163-197. 